\title{
THE MODEL OF CORRUPTION COURT BASED ON IT IN THE ARCHIPELAGO PROVINCE AS A QUICK, LOW COSTS, AND SIMPLE IMPLEMENTATION PROCESS
}

\author{
Sulistyanta; Aksi Sinurat; Jauhari Effendi; Fatma Ayu Jati Putri \\ Faculty of Law, University of Nusa Cendana \\ Email: soelistyanta@g mail.com.
}

\begin{abstract}
The enactment of Law Number 46 Year 2009 on The Corruption Court, is authorized to examine and decide the crime of corruption cases proposed by KPK or Prosecutor. Based on Article 35 paragraph (1) jo paragraph (4) of Law Number 46 of 2009, confirmed that corruption courts (Tipikor courts) are only located in each provincial capital whose jurisdiction covers the province concerned. By this provision, the Prosecutor Office in each district/city must transfer the corruption cases to the Corruption Court in the provincial capital. There are the problems as the following: first one, Is the process of criminal justice in the archipelago province (like NTT) able to fulfill the judicial principle of quick, low cost and simple?; second one, Is this condition not an obstacle in the process of criminal law enforcement in NTT?; The result of this research is that the Corruption Court in Kupang, conducted by several Prosecutor Offices, the samples do not meet the judicial principles of quick, low costs and simple. The obstacles besides spending much expenses, there are other factors such as weather, intentionally neglect the obligation as the experts, witnesses due to long time and high expenses. Law enforcement becomes less maximal due to the existing budget, and it can only be done by a minimal law enforcement process with a fairly expensive cost.
\end{abstract}

Keyword (Keywords): Trial, Criminal Court, Archipelago, Expenses incurred.

\section{A. INTRODUCTION}

Law enforcement is a process of enforcing legal norms in a real way. Norm or rule is a guidelines of behavior in the state society life. The criminal law enforcement process conducted by a system called the criminal justice system. As a system, the criminal justice system is a work mechanism undertaken by some components such as police sub-systems, prosecutorial sub-systems, court sub-systems and sub-systems of penitentiaries. Some of these sub-systems are cooperating to achieve goals. Court (criminal) as a sub-system of the criminal justice system has a purpose to uphold truth and justice.

Criminal law enforcement procedure (material) is regulated in criminal law and criminal procedural law. The main source of criminal procedure law is the Criminal Procedure Code. In addition there is a special criminal procedural rule. Special criminal procedure law is contained in legislation outside the Criminal Procedure Law (KUHAP) and 
Penal Code $(K U H P)$ as in the Crime of Corruption Law. Thus, there is a general criminal procedure law $(K U H A P)$ and special criminal procedural law (outside KUHAP). Substantially, it is stipulated that the general criminal procedural law (Criminal Procedure Code) remains in force unless otherwise stipulated.

In connection with the judiciary, in Indonesia, there are several courts such as the General Courts, State Administrative Courts, Military Courts and Religious Courts. The existence of the Corruption Court is including in the General Court (Article 2 of Law Number 46 of 2009 about the Corruption Court that the Corruption Court is a special court within the General Courts).

According to Law Number 46 of 2009, corruption court is a court authorized to examine and decide the cases of corruption both proposed by the KPK or by the Prosecutor (State and High). Based on Article 35 paragraph (1) jo paragraph (4) of Law Number 46 of 2009 affirms that the Corruption Court established in each provincial capital for the first time, whose jurisdiction covers the area of the province's laws. By the existence of these provisions, the prosecutor office in every district / city must transfer the case to the Corruption Court in the capital province.

Those provisions cause a problem especially in the area of East Nusa Tenggara (NTT) which is an archipelago province. NTT Province consists of 21 (twenty one) districts and 1 (one) city spread across several islands. Geographically, NTT consists of several large and small islands. Large islands such as Timor, Flores and Sumba, while the other islands are relatively smaller such as, Sabu island, Rote island, Alor islands (Alor island and other small islands), Solor islands, Adonara, Lembata, Semau Island, and others as shown in the map below:

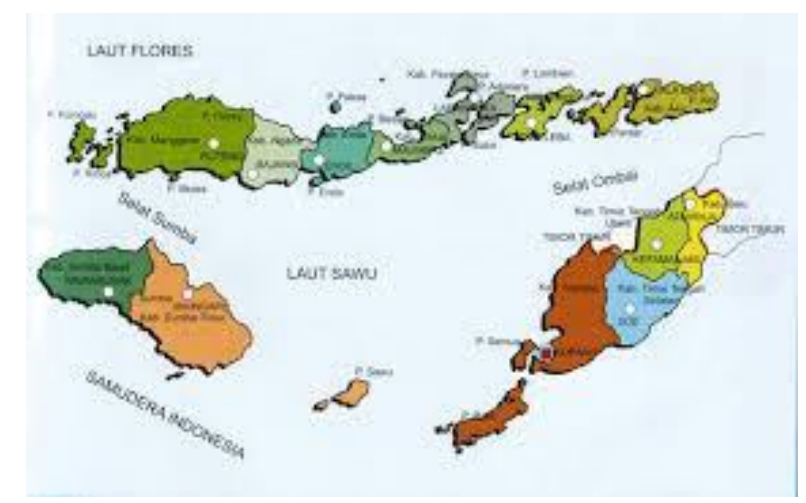

East Nusa Tenggara Province 
By the existence of the Corruption Court (Tipikor) in the provincial capital raises the issue that if the Prosecutor Office in NTT handles a case of corruption, and will prosecute in the trial of Corruption Court in the provincial capital, they have to travel far enough. This trip certainly cost a considerable amount. The costs include for transportation, accommodation for law enforcement, witnesses and so on. On the other hand, according to Article 50 paragraph (1) of the Criminal Procedure Code (KUHAP) it has been affirmed that the judicial principles are quick, simple and low costs. Those principles are as a guarantee for certainty, and justice.

\section{B. PROBLEM STATEMENTS}

1. Why the process of corruption court in archipelago province like in NTT is difficult to fulfill the judicial principles of quick, low costs and simple?

2. What are the obstacles that arise in relation to the process of law enforcement of corruption in the archipelago province like in NTT?

\section{RESEARCH METHODS}

This research is conducted descriptively which means all the primary data that have been collected are analyzed descriptively. The costs incurred by the state prosecutor apparatus in order to enforce the law is to sue the perpetrators of corruption in their respective jurisdictions. In research year I (one) it was directed to detect / describe all costs incurred in the law enforcement. This description is important to illustrate that the great distance between the court and the location where the Prosecutor Office is, takes the great cost. The location of Research Year I: conducted at the Prosecutor Office in East Nusa Tenggara Province: (1) Prosecutor Office of West Manggarai, Flores island (2) Prosecutor Office of Ende, Flores island (3) Prosecutor Office of Maumere, Sikka, Flores island (4) Prosecutor Office of Lembataa, Lembata island, (5) Prosecutor Office of Kalabahi, Alor island, (6) Prosecutor Office of Waikabubak, West Sumba, Sumba island (7) Waingapu Prosecutor Office, East Sumba, Sumba island, and (8) Prosecutor Office of Kefamenanu, TTU, West Timor island. Samples and sampling: 8 Prosecutor Office's samples scattered in some of those areas have represented the 21 (twenty-one) Prosecutor Office's population. The selection sample ofProsecutor Offices was chosen purposively by considering the distance criteria of Corruption Court in Kupang and representing the islands in NTT. Primary and secondary data collection: Secondary data collection is collected by reading journals, research reports, library books which are relevant to the research topic or purchasing the required books. 
While the primary data collection (field): conducted directly to the location. Conducting interviews with the appointed informants i.e. Chief Prosecutor and or with the represent one, Special Criminal Attorney (Jampidsus). The interview was conducted based on the questionnaire (open). Data analysis is obtained descriptively: The collected primary data are edited, coded and tabulated by then. The analysis is adjusted to the issues that will be answered which is related to the frequency of cases in the last 3 (three) years, the use expenses to solve a case of corruption, the completion time of corruption cases, the frequency of trials conducted in the Corruption Court in Kupang. The data are presented in either simple or narrative frequency table which is included in the explanatory / analytical descriptions.

\section{Literature Review}

\section{Principles of Criminal Procedure Law: quick, low cost, and simple}

The word 'principle' literally means basic meaning, fundamental, starting, ground, and / or joints. (YahyaHarahap: 1993) in the context of justice law, a principle of law becomes the fundamental or general reference for the courts in solving cases, so the judges' ruling has strong joints and norms to create the expected law objectives for the litigants.

In Article 5 paragraph (2) of Law Number 4 of 2004 on judicial power proposed that courts are assisting justice seekers and strive to overcome all obstacles and barriers to achieve the simple, quick, and low costs justice. Article 4 paragraph (2) of Law Number 4 of 2004 confirmed that the judiciary is done in simple, quick, and low costs way. In the explanation, it is known that "simple" means the examination is done efficiently and effectively, clear procedure, easy to understand and not convoluted, while the "low costs" means the costs of the case can be paid by the civil people. Low costs in this case means no other costs are required unless there is a necessary cost in real terms for settlement of cases such as, the cost of administration, the registration of the case, the cost of witnesses, expert witnesses, stamp cost. Then what is mean of "quick" in judicial principle means that the settlement of the case takes not too long time. However, the quick settlement should always run on the right, fair and conscientious law rules.

The implementation of these principles should not decrease the accuracy of judicial and legal checks and judgments. If the simple, quick, low costs principles become the spirit of law enforcement, an effective and efficient criminal justice system can be created (Mukti Arto: 2001). The criminal justice process in low costs means to avoid the administrative system of the case and the mechanisms of the working officers which can result the not 
comparable cost with the interest of social cost, in other words the costs are higher and the expected outcomes are lower ( Bambang Poernomo: 1993). If all these factors are maximized, it is not impossible that the criminal justice system will be better and will create a clean, fair, objective and fair judiciary (Mafta Setiawan: 2014).

\section{The Corruption Court}

In the context of Indonesia Law State, Article 24 paragraph (1) of the 1945 Constitution amendment determines: Judicial power is an independent power to administer justice in order to uphold law and justice. Judicial power is exercised by a Supreme Court and the lower courts within the general court, the religious court, the military court, the state administrative court, and by a Constitutional Court.

The Court of Corruption in Indonesia is essentially a judicial power whose authority derives from the power of the Indonesia legal state to receive, examine, judge and decide the cases of corruption in order to uphold law and justice based on Pancasila and the 1945 Constitution. The Corruption Court is a special court within the General Court and take placein each provincial capital which have the authority to examine, judge and decide several cases: corruption, money laundry which is originally a criminal act of corruption, and / or a criminal act which in the other Laws is determined as a criminal act of corruption as well.

The establishment of a Corruption Crime (Tipikor) Court located in Kupang based on the Decision of the Chief Justice of the Supreme Court of the Republic of Indonesia Number: 022 / KMA / SK / II / 2011 dated February 7, 2011 on the Operation of the Corruption Court in several regions in Indonesia.

In relation to the principles of quick, simple and low costs as a general principles of criminal procedure law, it also can be found in Article 29 of Law Number 46 of 2009 on Corruption Courts that corruption cases are examined, judged and decided by the first level of Corruption Court within 120 (one hundred and twenty) of working days from the date of the case to the Corruption Court. In connection with the Corruption Court which is only located in provincial capital of NTT in Kupang raises some problems in enforcing the law when it is associated with a quick, simple and low costs judicial principles. Since the NTT province consist of islands of the Prosecutor Office's which are equivalent to district areas are also spreading in some of these islands, which is geographically far enough from the provincial capital. 


\section{Archipelago Province and the Model of Court based on Information Technology}

Archipelago province is defined as an area withaquatic terrestrial characteristic (the sea is larger than the land) such as Maluku Province, which is $92.6 \%$ sea territorial, Riau Islands Province is 96\%, East Nusa Tenggara is $80.8 \%$, Province of Bangka Belitung Islands is $79.9 \%$, West Nusa Tenggara Province is $59.13 \%$, North Sulawesi Province is $95.8 \%$, and North Maluku Province is $69 \%$ sea territorial. Besides aquatic terrestrial, the regions in Indonesia aredivided into terrestrial (entirely mainland) and terrestrial aquatic (the land is larger than the sea) regions. Terrestrial and terrestrial aquatic regions have many advantages than aquatic terrestrial regions. In the aquatic terrestrial region which is known as the archipelago, the people tend to be isolated because they do not have access in various sectors, especially education, health, economy, politic and socio-culture.

There are some unique and special characteristics that found in the archipelago (AkhmadAulawi: 2012), firstly, the vast sea area is greater than the land area. Secondly, in terms of demographic distribution, the archipelago population is usually relatively small and its distribution is uneven. Thirdly, in terms of socio-culture, the communities in the archipelago region are segregated in settlements according to the territorial of an island, so it is commonly implicated as the strong sense of attachment to the land (read: islands), the pattern of life on small islands is more like to be in harmony with nature (slow to accept some changes). Next, in terms of socio-economy, economic activity, types and degrees of economic dynamics are generally limited and in small scale, and not yet supported by adequate distribution and marketing networks. Last, in terms of environment, the environmental resources are in limited amount, vulnerable to change (entropy), prone to natural disasters (waves in the sea are dominated by wind-induced gravitational waves, ocean currents caused by two factors: seasonal winds and tides). The archipelago have different characteristics with the continental regions so that the model of infrastructure development is different too. All this time, the attention to the economy development and the other sectors are delayed so that the archipelago regions are relatively isolated.

The archipelago region requires a juridical effort to empower and raise its people from poverty and misery. The juridical efforts for archipelago regions are a normative arrangement as a special treatment. Similarly, the access to justice with the development in 
technology can certainly help the isolated areas and / or can press the expenses which is spent by the justice seekers by accessing the justice more easily.

\section{Court Model based on Information Technology}

\section{a. The Model Concept}

A model is a simplification system in nature that can be used in decision making becomes easier (Suratmo: 2002). According Soedijono (Soedijono: 1995), a model is a picture of an object that is composed to recognize the behavior of object by looking for interrelations between the elements, making predictions to improve the state of the object and to optimize the object. The function of a model is to describe as closely as possible with the condition of the object observed in accordance with the purpose of modeling. Through a model, someone can do an experiment on model without disturbing an object and can create a picture of the future (Eriyatno: 1998; Winardi: 1999). Quantitative models are models in the form of mathematical and statistical formulas, while the qualitative model or analog model is an image-shaped model or diagram that generally borrows other systems that have similar characteristics with an object. Qualitative or analog models could show the dynamic nature of the object better. Between the model and the reality there must be an equation so that the model can be used properly (Winardi: 1999). Same with Ford (Ford: 1999) who defines the model as a substitute for the actual system to facilitate work. From operational research terminology, the model is defined as a representation or abstraction of an object in an actual situation. The model shows both direct and indirect relationships and reciprocal links in terms of cause and effect. Since the model is an abstraction of reality, it is less complex than reality itself. The model can be said complete if it can represent the various aspects of the reality which are being studied.

\section{b. The use of Video and Teleconference in the court trial}

The rearrangement and improvements in the management system of judicial institutions in the country are seen as very important things due to the high democratic demand of the development of an Indonesian society that require more effective, efficient, professional, transparent, accountable and reliable judicial system. (JimlyAsshiddiqie: 2003). Therefore, almost all law enforcement agencies in the country face the same issues such as less responsive and outdated administrative and management issues in facing the development of societies demanding access to justice fairer, and more efficient and transparent inlegal services (JimlyAsshiddiqie: 2003). 
According to the experts (JimlyAsshiddiqie: 2003) what is desired by the consumer, or in this case the justice seekers, from the operation of the system and the functions of management are: (i) productivity; (ii) quality of results; (iii) low costs; (iv) efficient in terms of time; (v) safety; (vi) hygienic or health; And (vii) achieving the functional objectives effectively. The results are expected to be obtained by using various available tools, which consist of hardware and software. Hardware consists of (a) human resources (personnel), (b) facilities, and (c) materials; while software consists of (a) technology, (b) system, and (c) management.

The good judicial governance requires the availability of comprehensive and accessible information and data base, also an effective and efficient communication. Therefore, the courts should utilize the service of information technology and modern communication as well as possible. Like computers, internet and hand-phone facilities are not only functioned for personal communication but also can be used for serious types of communication in efficient and effective way(JimlyAsshiddiqie: 2003).

The Internet should not only be used for sending email or making an accessible website for justice seekers but also can be usedto renew the way law-institution works, especially the courts in providing justice services. Internet and other electronic information materials should be treated as valid evidence in the judicial process. Similarly with the latest communication tools should be allowed to be utilized in judicial review and proceedings. The use of teleconference and video-conference facilities that are currently used to be practiced in the trials of the Constitutional Court can be developed into new conventions and customs.

The utilization of information and communication technology services in the judicial process can be done without having to wait for the regulations that allow it. It only takes the creativity of leadership and the leadership awareness to constantly update itself with all kinds of modern technologies that are useful for the efficiency and effectiveness of law enforcement and justice services. 


\section{E. Research Result and Discussion}

According to the research result, the data can be seen in:

Table 1. The Number of Corruption Crime Cases in the last 3 years (2014-2016)

\begin{tabular}{|c|l|c|}
\hline No. & \multicolumn{1}{|c|}{ Prosecutor Office } & Number of Case \\
\hline $\mathbf{1 .}$ & Prosecutor Office of Manggarai Barat & 7 cases \\
\hline $\mathbf{2 .}$ & Prosecutor Office of Manggarai & 11 cases \\
\hline $\mathbf{3 .}$ & Prosecutor Office of Ende & 10 cases \\
\hline $\mathbf{4 .}$ & Prosecutor Office of Maumere & 7 cases \\
\hline $\mathbf{5 .}$ & Prosecutor Office of Lembata & 16 cases \\
\hline $\mathbf{6 .}$ & Prosecutor Office of Alor & 5 cases \\
\hline $\mathbf{7 .}$ & Prosecutor Office of Waingapu & 17 cases \\
\hline $\mathbf{8 .}$ & Prosecutor Office of Waikabubak & 82 cases \\
\hline & Total & \\
\hline
\end{tabular}

Data Source: primary data processed in 2016

In the table 1 from the total 82 (eighty two) cases in the last 3 (three) years, inaverage, every 3 (three) years is 82: $3=11$ (eleven) Corruption Crime cases. Based on the average of 11 (eleven) cases, it can be calculated that every year, on average, there are 3 (three) cases, except the West ManggaraiProsecutor Office (7 cases), Maumere (7 cases) and Waingapu (5 cases). Based on DIPA (TA 2014 and TA 2015) for Prosecutor Officein the Prosecutor Office's region in NTT each year is budgeted Rp 558.840.000, - for all stages (preliminary investigation, full investigation, pre-prosecution, prosecution and execution). From the total costs, for the prosecution takes Rp 190.000.000, - (primary and secondary data: processed in 2016).

The total costs $\operatorname{Rp} 558,840,000$, - is estimated to be sufficient to afford 3 (three) cases. However it still depends on the existing case, whether the proof is relatively easy or not. Thus, if there are more than 3 (three) cases in one year, it is estimated that there will be case arrears which will be settled with the next year budget. This situation becomes wrong because the cumulative case can be a bad precedent for law enforcement.

In connection with the use of the budget, one of them is influenced by the frequency of the trial (prosecution stage) which means how long it takes to decide the corruption 
crimecase. The frequency of trials conducted by the Prosecutor Office's sample as written in Table 2.

Table 2. Trial Frequency of each crime of corruption case in Corruption Court in Kupang

\begin{tabular}{|c|l|c|}
\hline No. & \multicolumn{1}{|c|}{ Prosecutor Office } & Months - Trial Frequency \\
\hline 1. & Prosecutor Office of Manggarai Barat & 3 months, 10-16 times \\
\hline 2. & Prosecutor Office of Manggarai & 3 months, 12 times \\
\hline 3. & Prosecutor Office of Ende & 2 months, 10 times \\
\hline 4. & Prosecutor Office of Maumere & 3 months, 18 times \\
\hline $\mathbf{5 .}$ & Prosecutor Office of Lembata & 6 months, 20 times \\
\hline 6. & Prosecutor Office of Alor & $2-3$ months, 10 times \\
\hline 7. & Prosecutor Office of Waingapu & 3 months, ----- \\
\hline 8. & Prosecutor Office of Waikabubak & 3 months, 12-15 times \\
\hline
\end{tabular}

Data Source: primary data processed in 2016

According to the Table 2 above, it can be seen that the frequency of the crime of corruption trials in Kupang Corruption Court takes an average of 2-3 months (according to the 150-day detention period from the authority of the prosecutor and court judges) and requires $10-20$ trials.

For further explanation, here are the details of spent expenses by the Prosecutor Office in conducting the prosecution stage at the Corruption Court in Kupang:

1. Prosecutor Office, the sample taken from the west side of Sumba island:

The Prosecution Stage in the Corruption Court in Kupang

1. The consumption cost for public prosecutor, prison officer / defendant $=\mathrm{Rp}$. $6,912,000$

2. The consumption cost for witness, expert, translator $=\mathrm{Rp} 1.152 .000$

3. Honorarium for expert / translator $=\operatorname{Rp} 2.600 .060$

4. The cost for preparing and drafting a prosecution plan $=\operatorname{Rp} 630,000$

5. The cost for the defendant security $=\operatorname{Rp} 6,000,000$

6. The cost to shuttle the defendant $=\operatorname{Rp} 8,000,000$

7. The cost for summoning witness, expert, translator $=\operatorname{Rp} 28.800 .000$

8. Accommodation fee $=\operatorname{Rp} 7.200 .000$

9. Daily Charge $=$ Rp 18.240.000 
10. The transportation costs for trial prosecutor $=\mathrm{Rp} .48 .000 .000$

Total expenses $=\operatorname{Rp} 127.534 .000$

(Data source: the primary data processed in 2016)

2. Prosecutor Office, the sample taken from the east end of Flores island:

The Prosecution Stage in the Corruption Court in Kupang

1. The consumption cost for witnesses, experts, translators ( 28 persons $\mathrm{x} 3$ times $\mathrm{x}$ 20 trials $)=\operatorname{Rp} 2.016 .000$

2. The consumption cost for Public Prosecutors, prison officers / defendant (8 persons x 3 times $\mathrm{x} 20$ trials) $=\mathrm{Rp} \cdot 17.280 .000$

3. The transportation costs for trial prosecutors ( 3 persons $\times 20$ times $)=R p$ 120.000 .000

4. The cost for summoning witnesses, experts, translators $(28$ persons $\mathrm{x} 1$ case $)=\mathrm{Rp}$. 40.000 .000

5. Accommodation fee ( 3 persons $\times 20$ times $\times 1$ case $)=R p \cdot 18.000 .000$

6. Accommodation fee for witnesses, experts ( 20 persons $x 1$ case $)=7.200 .000$

7. Daily fee for the public prosecutors dan the prison officers ( 3 persons $\mathrm{x} 2$ days $\mathrm{x}$ 20 times $x 1$ case) $=$ Rp. 45.600 .000

8. The cost for preparing and drafting a prosecution plan $=\mathrm{Rp} .1 .000 .000$

9. The cost for the experts/translators ( 4 persons $x 1$ case $)=R p .8 .000 .000$,-

10. The cost for the defendant security( 5 persons $\times 20$ times $\times 1$ case $)=R p$. 15.000 .000

11. The cost to shuttle the defendant $(20$ times $x 1$ case $)=\operatorname{Rp} 20.000 .000$

Total expenses $=\operatorname{Rp} 294,096,000,-$

(Data source: the primary data processed in 2016)

3. Prosecutor Office, the sample taken from the middle of Flores island: The Prosecution Stage in the Corruption Court in Kupang

1. The consumption cost for the public prosecutors, prison officers and the defendant $=$ Rp. 20.736 .000

2. The cost of transferring the draft and the preparation for indictment plan letter $=$ Rp. 2.000 .000

3. The cost of consumption and expenditure of indictment letter= Rp. 1.000 .000

4. The transportation cost for the team with the defendant when transferring the case 
to Kupang= Rp. 4.500 .000

5. The security cost $=$ Rp. 18.000 .000

6. The cost to shuttle the defendant= Rp. 24.000 .000

7. The cost for summoning witnesses, experts, translators= Rp. 86.000.000

8. Accomodation fee $=$ Rp. 21.600 .000

9. Daily charge $=$ Rp. 54.720 .000

10. The transportation cost for the trial $=\mathrm{Rp} .144 .000 .000$ Total Expenses = Rp. 376,556,000,-

(Data source: the primary data processed in 2016)

4. Prosecutor Office, the sample taken from the west end of Flores island: The Prosecution Stage in the Corruption Court in Kupang

1. Flight Tickets $=3$ prosecutors $\times 16$ trials $\times 2$ round trips $\times 2.000 .000=R p$. 192.000.000

2. Hotel $=3$ prosecutors $x 2$ days $\times 16$ trials $\times 350.000=$ Rp. 33.600 .000

3. Accommodation fee $=3$ prosecutors $\times 16$ trials $\times 3 \times 300.000=R p .43 .200 .000$

4. The transportation cost/car rental= 16 trials $x 450.000=\mathrm{Rp} .7 .200 .000$

5. Flight tickets for the witnesses $=12$ witnesses $\times 2$ round trips $\times 2.000 .000=R p$. 48.000 .000

6. Hotel for the witnesses $=12$ witnesses $x$ 2days $x 350.000=$ Rp. 8.400 .000

7. The consumption cost for the witnesses $=12$ witnesses $\times 6$ portion $\times 40.000=R p$. 2.880 .000

8. Flight tickets for the experts $=2$ persons $\mathrm{x} 2$ round trips $\mathrm{x} 2.000 .000=\mathrm{Rp}$. 8.000 .000

9. Accomodation for the experts $=2$ persons $x 2$ days $x 300.000=R p \cdot 1.200 .000$

10. Hotel for the experts $=2$ persons $x 2$ days $x 350.000=$ Rp. 1.400 .000

11. Honorarium for the experts $=2$ persons $x 2.500 .000=R p .5 .000 .000$

12. The cost for summoning the witnesses $=12$ witnesses $\mathrm{x} 2$ summons $\mathrm{x} 30.000=\mathrm{Rp}$. 720.000

13. The cost for summoning the experts $=2$ persons $\times 2$ summons $\times 30.000=R p$. 120.000

14. Coordination fee $=$ Rp. 1.500 .000

15. Stationery fee $=$ Rp. 1.000 .000

Total expenses $=$ Rp. 354,220,000,- 
(Data source: the primary data processed in 2016)

According to the primary data above, it can be seen that the total expenses required for the prosecution of 1 (one) case in the corruption trials in Kupang in severalProsecutor Offices are various, i.e. Rp.127.534.000, -, Rp. 294,096,000, -, Rp. 376,556,000, - and Rp. $354,220,000$, - It is also seen that the greater the distance from Kupangcity, the greater the cost. The most important thing is that the total expenses have exceeded the cost limit for the prosecution whichthe amount has been determined previously; Rp. 190,000,000, -. Thus it can be concluded that the farther the distance and the longer the trial process takes time, the greater the cost.

Generally, costs are intended for transport or round-trip, accommodation (hotel), meals for the prosecutors, witnesses, experts, prison officers and defendant (one time). For example, the Prosecutor Office which is the farthest one from the Corruption Court in Kupang located in the western side of Flores island takes Rp248.000.000, for flight ticket round trip (Public Prosecutors, witnesses, experts) plus local transportation (car rental) during the trials in KupangRp 7.200.000, -, for hotels (combined amount) Rp.43.400.000, accommodation Rp 44.4 million, - even the daily charges is not included yet for the Public Prosecutors, expert fees, summoning fees of witnesses, and experts. The amount of this cost is almost similar to the Prosecutor Office sample from Sumba island. The amount of this fee is worth the distance that must be taken by the public prosecutor, the witnesses, experts, security and accused.

In connection with the great expenses, rises a question, could the enforcement of the law can be implemented maximally? Especially whenso many corruption cases are found in theProsecutor Office. It is for sure that the law enforcement could not be done optimally. The Prosecutor Office will set a priority scale which means not all cases can be prosecuted at once. Precisely, this priority scale can backfire to the Prosecutor Office. This is related to the demand of society who always ask for all cases to be prosecuted. If it is not done then the society will assume that the Prosecutor Office is not serious to prosecute. Seeing from the point of law, according to Lawrence M. Friedman (Lawrence M. Friedman: 2009: 18) it can affect the level of trust to the court which means there is no use to solve a case in the court.

The cost of prosecutorial cases that are perceived to be insufficient, will become more insufficient if some problems arise in the execution of the defendant. It meansthat when the defendant has been released from detentionbecause the expiry of the detention period, could 
cause him to "escape" from NTT. Certainly, to track the "runaway" defendant, it will take costs. Similarly, if the defendant is sentenced freely and / or free from indictment, it will increase the cost that must be incurred because there is a possibility of Public Prosecutor using the appeal and / or cassation and or vice versa, the defendant through his / her legal counsel to appeal and / or cassation.

Another issue is that the judge's decision on the amount of the state financial loss, as a result of corruption, is smaller than the cost of prosecuting in corruption trial. As shown in Table 3 below:

Table 3: The amount of money compensation for financial losses of the State that was decided by Kupang Crime of Corruption judge in 2014, 2015 and 2016

\begin{tabular}{|c|c|c|}
\hline No. & $\begin{array}{c}\text { The Decision of Crime of Corruption } \\
\text { Judge in Kupang }\end{array}$ & Total Money Compensation \\
\hline 1. & $\begin{array}{l}\text { No. 01/PID-SUS/2014/PN KPG } \\
\text { (cases in Sumba Timur) }\end{array}$ & $\begin{array}{l}\text { Rp. } 32.257 .818,- \\
\text { (5 years imprisonment) }\end{array}$ \\
\hline 2. & $\begin{array}{l}\text { No. 20/PID-SUS/2014/PN KPG } \\
\text { (cases in Rote Ndao) }\end{array}$ & $\begin{array}{l}\text { Rp. } 78.157 .980,- \\
\text { (4 years imprisonment) }\end{array}$ \\
\hline 3. & $\begin{array}{l}\text { No. 25/Pid-Sus/2014/PN Kpg } \\
\text { (cases in Alor) }\end{array}$ & $\begin{array}{l}\text { Defendant I Rp. 27.000.000,- } \\
\text { (1 year imprisonment) } \\
\text { Defendant II Rp. } 50.000 .000,- \\
\text { (1 year imprisonment) }\end{array}$ \\
\hline 4. & $\begin{array}{l}\text { No. 45/Pid-Sus/2014/PN Kpg } \\
\text { (cases in Manggarai) }\end{array}$ & $\begin{array}{l}\text { Rp. 451.979.107,- } \\
\text { (4 years imprisonment) }\end{array}$ \\
\hline 5. & $\begin{array}{l}\text { No. 16/Pid-Sus.TPK/2015/Kpg } \\
\text { (cases in Alor) }\end{array}$ & $\begin{array}{l}\text { Rp. } 10.000 .000,- \\
\text { (2 years imprisonment) }\end{array}$ \\
\hline 6. & $\begin{array}{l}\text { No. 75/Pid-Sus-TPK/2015/Kpg } \\
\text { (cases in Ende/Flores) }\end{array}$ & $\begin{array}{l}\text { Rp. } 100.000 .000,- \text { and } \\
\text { (1 year and } 6 \text { months imprisonment) }\end{array}$ \\
\hline 7. & $\begin{array}{l}\text { No.12/Pid-Sus-TPK/2016/Kpg } \\
\text { (cases in Sumba Timur) }\end{array}$ & $\begin{array}{l}\text { Rp. } 144.696 .760,43,- \\
\text { (1 year imprisonment) }\end{array}$ \\
\hline
\end{tabular}

Source: Kupang Corruption Court in 2016. 
Economically, the costs incurred to enforce the law should be less than the financial loss of the state which is must to return to the state. Otherwise "the optimization of law enforcement will not come true" (Mahrus Ali: 2016: 226). While there is no advantage in economy during law enforcement, allowing non-prosecution case may cause a bad precedent for law enforcement itself.

Thus, is the prosecution of corruption crime cases in archipelago province, such as NTT based on economic calculations, could fulfill the judicial principles of quick, simple, (especially) low costs? In the researchers' opinion: it could not fulfill these principles because there are various obstacles in the prosecution process in corruption court. In order to hold the trial, it will take a long time (2-3 months average), the great distance which takes great cost, simultaneously could impact on law enforcement of corruption case.

Besides the issue of cost, the application of quick, cheap and simple judicial principles at the prosecution stage of corruption trial in the archipelagic province contained obstacles. Those obstacles can be identified as follows:

1. Time: the corruption trial process in Kupang could take a long time, the trial is postponedoftenly. One of the factors is the ratio of the number of cases and the available judges are 9 (Nine) people consist of 5 (five) career judges and 4 (four) Ad hoc judges divided into 5 (five) court assemblies. While the volume of cases is large enough to include 122 cases (2014), 102 cases (2015 and 97 cases (until September 2016). (Source data: primary data processed in 2016.) The postponement of the trial causing the number of the cases become lot and the trial schedule become hectic. Plus the absence of witnesses, prosecutors, lawyers and / or defendants for various reasons such as sickness, etc could postpone the trial. The consequences of trial postponement could affect the cost, and the departure of the public prosecutor to Kupang is the cause of another case which is being dealt with the public prosecutors became obstructed.

2. Internal factors of witnesses, experts / translators. Long distances make them leave their jobs (permission not to work) and will be more chaotic when the trial schedule is often delayed. On the other hand they must fulfill their obligations as witnesses. If these witnesses are summoned by law enforcement officers and intentionally unwilling to come (fulfill the summons), under Article 224 of the Criminal Code is 
threatened with criminal sanctions. Article 224 of the Criminal Code: Whoever is called as a witness, expert or translator by law and intentionally fails to comply with the obligations under the law to be fulfilled, threatened: (1) in a criminal case, with a maximum imprisonment of nine months; (1). In another case, with a maximum imprisonment of six months.

3. Weather: generally weather become obstacles for flights to the NTT area in certain months. This condition could give an effect on the smoothness of air transportation. For example, when there is a trial in Kupang and the public prosecutor in the Prosecutor Office ofManggarai (Ruteng) Flores island want to go there, his or her departure will be delayed due to weather condition. Alternatively, she or he can look for another flight from the nearest airport in Labuan Bajo (West Manggarai District) and to get to the nearest airport could be by driving. Or look for other alternatives via airport in Maumere or Ende and to reach those two airports must be driving first. Driving takes a long time, and quite tiring. Surely, in terms of cost becomes greater because it is not only in the cost of transportation, but also in consumption and or hotel (if needed).

\section{F. Closing}

\section{Conclusion}

Based on the discussion above, it can be summarized that:

a. Prosecutor Office sample in archipelago province (NTT) for prosecution in corruption courts in Kupang require considerable cost, time and effort to meet the judicial principles of quick, low cost and simple. In addition, holding corruption trials in archipelago region (long distances) depends on several factors such as, weather (bad weather causing fail to flight). Another effect in terms of taking-long-time causing the postponement of the handled cases, and could affect the witnesses and translators as well.

b. The law enforcement becomes less optimal because with the available budget and the existing conditions could only hold a minimal law enforcement.

\section{Suggestions}

The judiciary in Indonesia needs to create a corruption trial model based on archipelago provinceso the judicial principles of quick, low cost, and simple could be fulfilled. The model 
can be used for jurisdictions that have characteristics like the province of East Nusa Tenggara (NTT) which consists of several islands.

\section{G. ACKNOWLEDGMENTS}

The research result of the Postgraduate Grant year I funded by Kemenristek and Dikti set out in the letter of assignment of the implementation of research program Number 164 / UN.15.19.1 / LT / 2016 dated 25 -2-2016

\section{BIBLIOGRAPY:}

Ali, Mahrus, 2016, Hukum Pidana Korupsi (Corruption Law), Yogyakarta: UII Press.

Arto, Mukti, 2001, Mencari Keadilan (Kritik Dan Solusi Terhadap Praktik Paradilan Perdata di Indonesia) (Pursuing Justice (Criticism and Solution to Civil Justice Practice in Indonesia), Yogyakarta: Pustaka Pelajar Offset.

Eriyatno. 1998, Ilmu Sistem, Meningkatkan Mutu dan Efektivitas Manajemen (Improve Quality and Effectiveness of Management), Bogor: I PB Press

Ford, A. 1999. Modeling of Environment : An Introduction to Sistem Dynamics Models of Environmental Sistem. California: Island Press.

Friedman, M, Lawrence, 2009, Sistem Hukum Perspektif Ilmu Sosial (The Legal System A Social Science Perspective), terjemahan M Khosim, Bandung: Nusamedia.

Harahap, Yahya, 1993, Kedudukan Kewenangan dan Hukum Acara Peradilan Agama, Cet. II (Position of Authority and Law of religious Judicature, Second Edition). Jakarta: Garuda Metro Politan Press.

Verdict of the Chief of Indonesian Supreme Court Number: 022/KMA/SK/II/2011 Tanggal 7 Februari 2011 Tentang Pengoperasian Pengadilan Tindak Pidana Korupsi Di Beberapa Propinsi Di Indonesia.

Verdict of the Chief of Indonesian Supreme Court Number: 144/KMA/SKIVIII/2007 Tahun 2007 Tentang Keterbukaan Informasi di Pengadilan. 
Poernomo, Bambang, 1993, Pola Dasar, Teori-Asas Umum Hukum Acara Pidana dan Penegakan Hukum Pidana Basic Patterns, Theory-Principles in the Enforcement of Criminal Procedure Law), Yogyakarta: Liberty.

Suratmo, F. G. 2002,Panduan Penelitian Multidisiplin (Guideline of the Multydicipline Research), Bogor: IPB Press.

Winardi. 1999,Pengantar Tentang Teori Sistem dan Analisis Sistem (Introduction to Theory and Analysis of System), Bandung: Mandar Maju.

\section{Journals:}

Sukardi, Penerapan Asas Sederhana, Cepat dan Biaya ringan Dalam Pemeriksaan Perkara Pidana Penipuan di Pengadilan Negeri Pontianak, E - Jurnal, GLORIA YURIS, Vol 1 No.1 tahun 2012

Sawardi, Pelaksanaan Asas Peradilan Cepat Dalam Perkara Tindak Pidana Korupsi (Studi Terhadap Penerapan Pasal 29 Undang-Undang Nomor 46 Tahun 2009 Di Pengadilan Tindak Pidana Korupsi Pontianak), Vol 2 No.2 Tahun 2012, Jurnal Magister (S2): NESTOR, MAGISTER HUKUM, Universitas Pontianak.

\section{Regulation:}

Law Number 4 of 2004 on The Judicial Power Kehakiman

Law Number 46 of 2009 on The Corruption Court.

\section{Internet}

Akhmad Aulawi,Jalan Panjang Menuju Akselerasi Pembangunan Daerah Kepulauan, www.Gresnews.comaccessed on April 10 2015.

Asshiddiqie, Jimly, 2003, Reformasi Tata Kelola Peradilan,www.jimlyschool.com, accessed on March $12^{\text {th }}, 2015$.

Budi, Agus Susilo,Peran Teknologi Informasi dalam Memodernisasi Sistem Peradilan di Indonesiawww.ptun-yogyakarta.go.id, accessed on March $12^{\text {th }}, 2015$. 
Huda, Choirul, Manfaat Teknologi Keterbukaan Informasi di Situs Pengadilan Negeri Kepanjen, http://pn-kepanjen.go.idaccessed on March 12 $2^{\text {th }}, 2015$.

Setiawan, Mafta, Elektabilitas Penerapan Asas Peradilan Cepat, Sederhana dan Biaya Ringan Terhadap Hukum Pidana, http://matfa-setiawan.blogspot.com/2014/06/makalahelektabilitas -penerapan-asas.html\#.VT_ZF9lHmZQaccessed on March 12 ${ }^{\text {th }}, 2015$. 